\title{
Izazovi istraživanja otpornosti obitelji $^{1}$
}

\author{
Martina Ferić*, Ivana Maurović, Antonija Žižak
}

Odsjek za poremećaje u ponašanju, Edukacijsko-rehabilitacijski fakultet

Sveučilišta u Zagrebu

\section{Sažetak}

Otpornost je koncept koji se sve više istražuje u području psihosocijalnih znanosti. Time se ujedno i rasvjetljavaju brojne nejasnoće u konceptualiziranju i operacionaliziranju ovog fenomena. Kroz pedesetogodišnji razvoj, koncept je prošao put od usmjerenosti na pojedinca ka usmjerenosti na sve šira okruženja pojedinca (obitelj, zajednica, kultura). U skladu s time, nejasnoće nastale u području istraživanja individualne otpornosti selile su se u područja istraživanja otpornosti u sustavima poput obitelji ili zajednice. Cilj ovog rada je dati pregled različitih načina konceptualizacije otpornosti obitelji te navesti operacionalizaciju otpornosti obitelji u projektu Specifična obilježja obitelji u riziku: doprinos razvoju kompleksnih intervencija koje se provodi na Edukacijsko-rehabilitacijskom fakultetu Sveučilišta u Zagrebu.

Ključne riječi: otpornost, otpornost obitelj, izazovi konceptualizacije 


\section{UVOD}

Koncept otpornosti jedan je od najvažnijih koncepata u suvremenim društvenim znanostima (Liebenberg i Ungar, 2009). Njegovi začeci datiraju od polovice prošlog stoljeća, od kada se intenzivno razvijao. Prošao je put od usmjerenosti na individualne osobine koje doprinose dobrim ishodima djece u visokom riziku (nazvane neranjivom djecom), preko pomaka pažnje na okruženja u kojima djeca odrastaju sve do suvremenog shvaćanja važnosti interakcija između pojedinca i pretpostavljenih okruženja - obitelji, zajednice, kulture (O'Dougherty Wright, Masten i Narayan, 2013).

Otpornost je jedan od onih koncepata u društvenim znanostima pri čijoj konceptualizaciji i operacionalizaciji postoje brojni izazovi i pristupi. Definirajući otpornost različiti autori pažnju stavljaju na različite aspekte tog fenomena. Tako se jedni usmjeravaju na obilježja pojedinca ili obilježja obitelji/zajednice, drugi na procese, a treći na ishod. Isto tako, u literaturi je moguće naći pristupe otpornosti koji kombiniraju dva od tri navedena usmjerenja.

U skladu s tim, u Hrvatskoj je provedeno više istraživanja koja su pažnju usmjeravala na pojedine aspekte otpornosti pojedinaca/obitelji/zajednice. Primjerice, otpornost pojedinca kao procesa obuhvaćen je u radu Maurović (2015). Blažević (2012) je u svojem specijalističkom radu otpornost sagledala kao obilježje obitelji, dok je Mataga Tintor (2011) istražila različite perspektive poimanja otpornosti zajednice. Nadalje, brojna istraživanja obuhvatila su neke od komponenti otpornosti djece i mladih u riziku (rizike, zaštitne čimbenike, dobre ishode), bilo kroz izučavanje jedne od komponenti ili kombinacije tih komponenti, iako samo istraživanje nije nazvano istraživanjem otpornosti (primjerice Lebedina Manzoni, 2000, Sladović Franz, 2003, Vulić Prtorić, 2002, Koller Trbović, Žižak, Jeđud, 2009, Ferić Šlehan i Kranželić, 2008, Ferić Šlehan, 2008, Ajduković, Ručević i Šincek, 2008, Ricijaš, 2009, Mihić, Musić, Bašić, 2013, Žižak i sur., 2010).

Većina navedenih istraživanja, bez obzira je li u fokusu imala pojedinca, obitelj ili zajednicu, komponente otpornosti proučavala je iz perspektive pojedinca. Nedostaju istraživanja otpornosti cjelokupnog obiteljskog sustava. Logično je da kompleksnost istraživanja otpornosti raste kad se fokus premjesti s pojedinca na sustav. Istraživačima koji se odlučuju na taj pothvat od pomoći mogu biti brojni inozemni radovi, od kojih će neki biti navedeni u tekstu koji slijedi. Domaćih radova na tu temu je manje, odnosno pronađen je jedan do sada objavljeni rad koji se bavio pregledom teorijskih konstrukta otpornosti obitelji (Berc, 2012).

Slijedom navedenog cilj ovog rada je dati doprinos pregledu literature na temu otpornosti obitelji, odnosno dati pregled različitih načina konceptualizacije otpornosti obitelji te se osvrnuti 
na izazove prilikom njegove operacionalizacije u istraživanju Specifična obilježja obitelji u riziku: doprinos razvoju kompleksnih intervencija.

\section{OTPORNOST OBITELJI}

\section{Razvoj koncepta}

Koncept otpornost prvotno je nastao u prirodnim znanostima (Gauvin-Lepage, Lefebvre i Malo, 2014), da bi se pod utjecajem opće teorije sustava (von Bertalanffy, 1968, prema Masten i Monn, 2015), odnosno ideja o sličnim principima funkcioniranja humanih i nehumanih sustava (Janković, 2008), počeo širiti i na društvene znanosti. U društvenim znanostima prvo dobiva naziv psihosocijalna otpornost (Rutter, 1987), da bi se danas koristio samo termin otpornost.

Tijekom razvoja, koncept (psihosocijalne) otpornosti prošao je četiri vala (O'Dougherty Wright, Masten i Narayan, 2013). Svaki val istraživanja imao je drukčiji fokus. Prvi val započeo usmjeravanjem na pojedinca (Gramezy, 1974, Anthony, 1974, Murphy i Moriarty, 1976, Rutter, 1979, Werner, 1982, prema Masten, 2001), da bi se nakon toga u drugom valu fokus premjestio na istraživanje pojedinčevih okruženja i njihovog utjecaja na razvoj otpornosti (Masten i sur., 1990, prema O'Dougherty Wright, Masten i Narayan, 2013). U trećem valu istraživači su se usmjerili na razvoj intervencija temeljenih na rezultatima istraživanja (Masten, 2007), da bi u zadnjem valu došlo do pomicanja fokusa na višerazinsku interakciju, s jedne strane gena i neurobiološke prilagodbe, a s druge, različitih razina pojedinčevog okruženja (O'Dougherty Wright, Masten i Narayan, 2013).

Koncept otpornosti obitelji koji je u fokusu ovog rada pojavio se kao nadogradnja individualne otpornosti. Uz to, korijene vuče iz još jednog istraživačkog područja - istraživanja stresa, suočavanja i prilagodbe obitelji (Patterson, 2002a). Interes za proučavanje obiteljskog stresa započeo je 1920-ih, kada je Burgess (1926, prema Nichols, 2013) obitelj opisao kao cjelinu osobnosti koje su u interakciji. Od tada do danas, istraživani su različiti stresori kojima su obitelji bile izložene te su se, u skladu s teorijskim postavkama i rezultatima istraživanja, kreirali različiti modeli odgovora obitelji na stres. Tek 90 -ih godina prošlog stoljeća dobra prilagodba obitelji na stres počela se nazivati otpornošću obitelji (Sixbey, 2005). Razvoj koncepta otpornosti obitelji pod utjecajem istraživanja stresa prikazan je u Tablici 1. 
Tablica 1. Istraživanje stresa, suočavanja i prilagodne obitelji i razvoj koncepta otpornosti obitelji

\begin{tabular}{|c|c|c|}
\hline Razdoblje & Usmjerenost istraživanja/modeli & Autori \\
\hline 1930-te & $\begin{array}{l}\text { djelovanje ekonomske deprivacije } \\
\text { na obitelji }\end{array}$ & $\begin{array}{l}\text { Angell,1936, Burgess 1926, 1937, Cavan i } \\
\text { Ranck 1938, Morgan, 1939, Komarovsky's } \\
\text { 1940, prema Nichols, } 2013\end{array}$ \\
\hline 1940-te & $\begin{array}{l}\text { posljedice } 2 \text {. svjetskog rata na } \\
\text { obitelj } \\
\text { razvoj ABC-X modela obiteljske } \\
\text { krize }\end{array}$ & $\begin{array}{l}\text { Hill 1949, Boss, 2002, prema Wilmoth i } \\
\text { Smyser, } 2009\end{array}$ \\
\hline $\begin{array}{l}1950-\text { te } \\
1960-\text { te }\end{array}$ & $\begin{array}{l}\text { stresori u obitelji, poput } \\
\text { roditeljstva, bolesti, alkoholizma, } \\
\text { delinkvencije članova obitelji ili } \\
\text { odlaska u zatvor }\end{array}$ & $\begin{array}{l}\text { Gramezy, 1974, Anthony, 1974, Murphy i } \\
\text { Moriarty, 1976, Rutter, 1979, Werner, 1982, } \\
\text { prema Masten, } 2001\end{array}$ \\
\hline $\begin{array}{l}1970-\text { te } \\
1980-\text { te }\end{array}$ & $\begin{array}{l}\text { snage i sposobnosti koje obitelji } \\
\text { koriste kako bi se prilagodile } \\
\text { stresnim situacijama } \\
\text { razvija se Resiliency Model of Family } \\
\text { Adjustment and Adaptation }\end{array}$ & $\begin{array}{l}\text { Lavee, McCubbin i Olson, } 1987 \\
\text { McCubbin i Patterson, 1983a }\end{array}$ \\
\hline 1990-te & $\begin{array}{l}\text { uvođenje termina otpornost obitelji } \\
\text { u istraživanja }\end{array}$ & $\begin{array}{l}\text { McCubin i McCubin, 1992, prema Van } \\
\text { Breda, } 2001\end{array}$ \\
\hline
\end{tabular}

Jedno od prvih teorijskih objašnjenja o tome što doprinosi različitim reakcijama obitelji na stres, postavio je Hill (1949, prema Wilmoth i Smyser, 2009), proučavajući djelovanje stresa koji se pojavljuje zbog odsutnosti oca (tijekom 2. svjetskog rata) na obitelj. On je razvio ABC-X model obiteljske krize (Boss, 2002, prema Wilmoth i Smyser, 2009). Ovim modelom objašnjeno je kako interakcija triju elemenata ( , B i C) dovodi do krize u obitelji. Naime, izvori stresa (A) koji dolaze u interakciju s obiteljskim resursima (B) i definiranim značenjem stresnog događaja (C) zajedno dovode do značajno narušene ravnoteže u obitelji, odnosno do stanja krize $(X)$. Uz postavljanje teorijskih osnova koje su utrle put za razvoj drugih modela, Hillov model je značajan i zbog toga što je "doveo u pitanje" ideju da stresori uzrokuju krizu uvodeći nekoliko medijacijskih varijabli (npr. definicija situacije i resursa od strane obitelji) u taj proces, a koje su pod utjecajem obitelji. Time je implicirao postojanje mogućnosti osnaživanja otpornosti (Nicholos, 2013). 
Navedeni model je tijekom godina nadograđivan te je na temelju njega i brojnih drugih modela, poput: Double ABCX Model (McCubbin i Patterson, 1983a, 1983b), Family Adjustment and Adaptation Response Model (Lavee, McCubbin i Olson, 1983, McCubbin i Patterson, 1983a) te The Typology Model of Family Adjustment and Adaptation (McCubbin i McCubbin, 1987, prema Van Breda, 2001), nastao McCubbin-ov Resiliency Model of Family Adjustment and Adaptation. Riječ je o prvom sustavnom i ekološkom modelu otpornosti obitelji (Sixbey, 2005). Prema tom modelu, otpornost obitelji spoj je dva različita, ali povezana, procesa u obitelji: (I) prilagođavanje - uključuje utjecaj zaštitnih čimbenika u osnaživanju obitelji kroz jačanje sposobnosti i napora obitelji da zadrži integritet i funkcioniranje te ispuni razvojne zadatke u trenucima kada je suočena s rizičnim čimbenicima i (2) privikavanje - uključuje utjecaj čimbenika oporavka u promoviranju sposobnosti obitelji da se "dočeka na noge" i snađe u kriznim situacijama. Kakva će biti reakcija ovisi o težini stresne situacije, obiteljskog ciklusa u kojem se obitelj nalazi, prisutnosti obiteljskih resursa i podrške izvana. Nadalje, to ovisi i o neriješenim poteškoćama u novom načinu funkcioniranja obitelji, procjeni situacije te strategijama suočavanja.

Od devedesetih godina do danas moguće je prepoznati nekoliko pokušaja integriranja ideja iz različitih modela razvoja otpornosti obitelji (primjerice Patterson, 2002a, Patterson, 2002b, Masten i Monn, 2015, Henry, Scheffield Morris i Harrist, 2015). Henry, Scheffield Morris i Harrist (2015) navode kako se najveći dio integracije dogodio tijekom drugog vala istraživanja otpornosti. Danas je fokus na razjašnjavanju terminologije i postavljanju temeljnog modela istraživanja otpornosti obitelji.

\section{DEFINIRANJE OTPORNOSTI OBITELJI}

Početna istraživanja otpornosti obitelji bila su pod utjecajem pristupa orijentiranog na snage (Hawley, 2013) te su istraživači definirali otpornost kao obilježje obitelji (Henry, Scheffield Morris i Harrist, 2015). Tako McCubbin i McCubbin (247, 1998, prema Hawley, 2013) otpornost obitelji definiraju kao obilježja, dimenzije i svojstva obitelji koje im pomažu biti otpornima u slučaju nedaće. Istraživači su bili usmjereni na identificiranje obilježja, odnosno snaga otpornih obitelji te je razina navedenih snaga smatrana otpornošću. Kao snage obitelji najčešće se navode poštivanje i ljubav, pozitivna komunikaciju, predanost, duhovna dobrobit, zajedničko vrijeme i sposobnost nošenja s nedaćama (DeFrain i Asay, 2007). Ovakvo poimanje otpornosti obitelji, dominantno je i među 
Martina Ferić, Ivana Maurović, Antonija Žižak: Izazovi istraživanja otpornosti obitelji

praktičarima (Patterson, 2002a) za koje je otpornost obitelji sinonim za snage obitelji i „implicira kapacitet obitelji za uspješno nošenje s izazovnim okolnostima u životu" (Patterson, 2002b, 341).

Jedna od glavnih zamjerki ovakvom poimanju otpornosti obitelji je da u obzir ne uzima razinu rizika kojem je obitelj izložena, odnosno potencijalnu interakciju rizika i zaštitnih čimbenika (Ungar 2013). Ističe se važnost razdvajanja poimanja otpornosti obitelji od snaga obitelji (Patterson, 2002b, Walsh, 2003, Ungar, 2013).

U recentnim istraživanjima, otpornost obitelji definira se kao:

- „proces pomoću kojeg su se obitelji sposobne prilagoditi i kompetentno funkcionirati u situacijama izloženosti značajnom riziku ili krizi" (Paterson, 2002a, 352),

- "sposobnost obitelji da pozitivno odgovori na nedaću te "izađe" iz situacije ojačana, s više resursa i više povjerenja nego prije" (Simon, Murphy i Smith, 2005, 427),

- "dinamičan proces koji obuhvaća pozitivnu adaptaciju unutar konteksta značajne nedaće" (Luthar, Cicchetti i Becker, 2000, 543),

- „proces koji cilja smanjiti stres i ranjivost u visokorizičnim situacijama, promovirajući ozdravljenje i rast iz krize te osnaživanje obitelji da prebrode dugoročne nedaće" (Walsh, 2003, 5).

Navedene definicije objedinjuju kontekst, proces i ishod kao obilježja otpornosti obitelji.

Razumijevanje otpornosti kao procesa, sve je dominantnije u literaturi o otpornosti obitelji. Ovaj pristup ima brojne prednosti, a jedna od njih svakako je i mogućnost sagledavanja varijabilnosti fenomena. Utvrđeno je kako otpornost nije stabilna te kako ne treba očekivati da će osoba ili obitelj koja pokazuje otpornost u jednoj situaciji, biti otporna i u svim drugim situacijama izazova s kojima se može suočiti tijekom života i/ili razvojnog ciklusa obitelji (Masten i Powell, 2003). Naime, manifestacija otpornosti ovisi kako o osobnim/obiteljskim karakteristikama (zaštitnim čimbenicima/ mehanizmima) tako i o okolnostima (razvojna faza pojedinca i/ili obitelji, dostupni resursi i slično) u kojima se izazov pojavio te razini rizika koji predstavlja za pojedinca i/ili obitelj u tom specifičnom trenutku. Luthar (2006) ističe kako je riječ o atipičnom procesu budući da se pozitivna prilagodba događa u životnim okolnostima koje obično dovode do loše prilagodbe. Ističe i njegovu dinamičnost, definirajući otpornost kao dinamičan proces u kojem se ostvaruju dobri ishodi unatoč rizicima (Luthar i Ciccheti, 2000). Ungar (2011) naglašava kako je u tom procesu od iznimne važnosti dostupnost resursa u okruženju, ali i kapacitet pojedinca/obitelji da, pregovarajući s okolinom, koristi te resurse i usmjerava svoj put. Slično tome, Walsh (1998, prema Walsh, 2003) navodi kako 
je otpornost obitelji dinamičan proces izdržljivosti, samoupravljanja i rasta u odgovoru na krize i izazove. Obuhvaća ključne procese u odnosu na vrijeme, koji promiču sposobnost obitelji da nadvlada prepreke i zadrži svoje funkcije. Ista autorica navodi kako otpornost omogućava pojedincima i obiteljima uspješnu reakciju na krize i trajne izazove, ali i oporavak i rast iz tih iskustava.

Većina suvremenih autora slaže se kako je otpornost proces koji započinje rizikom, a završava neočekivano dobrim ishodom (Luthar, Cicchetti i Becker, 2000). Da bi taj proces bio moguć, potrebno je postojanje različitih zaštitnih čimbenika, na različitim razinama, koji u interakciji s rizicima potiču proces otpornosti (Windle, 2011). Dakle, otpornost je proces koji započinje rizikom, facilitiran je pomoću zaštitnih čimbenika, a završava dobrim ishodom. Rizik, zaštitni čimbenici/mehanizmi i dobar ishod su ključne komponente otpornosti.

U skladu s time, kao i općom teorijom sustava na koju se koncept otpornosti naslanja, Masten (2011) je ponudila obuhvatnu definiciju otpornosti prema kojoj je riječ o kapacitetu dinamičnog sustava da se odupre ili oporavi od značajnih izazova koji prijete njegovoj stabilnosti, održivosti ili razvoju.

Iz svega navedenog može se zaključiti kako postoji slaganje znanstvenika u konceptualizaciji koncepta otpornosti obitelji kroz komponente rizika, zaštitnih čimbenika i dobrog ishoda, no ipak ostaju otvorena pitanja vezana uz načine njihove operacionalizacije (Patterson, 2002a), o čemu će biti govora u tekstu koji slijedi.

\section{Definiranje komponenti otpornosti obitelji}

\section{Rizik}

U odnosu na operacionalizaciju rizika kao ključno postavlja se pitanje razine rizika s kojom se obitelj treba suočiti da bi se moglo govoriti o otpornosti. Neki autori smatraju da kao značajne treba uzimati normativne rizike, odnosno uobičajene životne krize, dok drugi zastupaju stav da razina rizika treba biti izrazito visoka, odnosno takva da značajno povećava mogućnost negativnih ishoda (Patterson, 2002b, Roisman, 2005, prema Windle, 2011). I dok je prvo poimanje prisutnije među praktičarima i nekim od istraživača, drugi je pristup dominantniji među većinom znanstvenika. Tako Masten i Coatsworth (1998) kao značajan rizik prihvaćaju onaj koji nastaje od: (1) visokorizičnog 
Martina Ferić, Ivana Maurović, Antonija Žižak: Izazovi istraživanja otpornosti obitelji

statusa uvjetovanog kontinuiranom, kroničnom izloženosti negativnim socijalnim uvjetima, poput siromaštva; (2) izloženosti traumatskim događajima, poput rata; (3) kombinacije visokorizičnog statusa i traumatskih iskustava.

Uz navedeno važno je imati na umu i kako jedan rizični čimbenik za sobom povlači druge rizične čimbenike te često dolazi do fenomena kumuliranja rizika, što stvara potencijalno veliku opasnost negativnih ishoda (Rutter i sur., 1995, prema Rutter, 1999). Stoga je u istraživanjima važno obuhvatiti veći broj mogućih rizika kojima je obitelj izložena. Nadalje, nije svejedno traje li neki rizik kratko (poput kratkotrajne nezaposlenosti) ili jer riječ o dugotrajnom riziku (dugotrajna nezaposlenost koja za sobom povlači i rizik od siromaštva). Također, pri sagledavanju opasnosti/ posljedica pojedinog rizika, važno je uzeti u obzir i obilježja razvojne faze u kojoj se nalazi pojedinac, odnosno obitelj (Simon, Murphy i Smith, 2005). Naime, postoji značajna razlika suočava li se obitelj s, na primjer nezaposlenošću roditelja, kada su djeca predškolske dobi ili kada su u mladenačkoj dobi te više mogu utjecati na načine kako se obitelj nosi s ovim rizikom.

Uz vrstu i razinu rizika koju je moguće mjeriti, otvaraju se pitanja poput: (1) tko procjenjuje rizike kojima je obitelj izložena (roditelji, djeca, svi zajedno, netko treći), treba li se usmjeriti samo na broj rizika (stresnih događaja) ili i na stupanj uznemirenosti s tim događajima te (2) koji je najbolji način prikupljanja podataka - samoprocjenom, procjenom ili nekim objektivnim kriterijem. Većina dosadašnjih istraživanja stresa oslanjala se na samoprocjenu pretpostavljajući kako je osoba koja ju situaciji stresa ipak najrelevantniji izvor informacija (Cole i sur., 2006, Kim i sur., 2006, prema Clements, Aber i Seidman, 2008).

Neki od instrumenta koji se najčešće koriste za procjenu rizika u kontekstu istraživanja otpornosti obitelji su:

- Family Inventory of Life Events and Changes (FILE, autori McCubbin, Patterson i Wilson, $1983^{2}$ ) - mjeri normativne i nenormativne životne događaje koji se koristi kao mjera obiteljskog stresa; ispunjavaju ga zajedno odrasli članovi obitelji; 71 čestica.

- Adolescent Family Inventory of Life Events and Changes (A-FILE, autori McCubbin i Patterson, Bauman i Harris $\left(1981^{3}\right)$ - mjeri obiteljski stres iz perspektive adolescenata te se koristi kao mjera obiteljskog stresa; 50 čestica.

2 http://www.mccubbinresilience.org/measures.html

3 http://www.mccubbinresilience.org/measures.html 
- Young Adult Family Inventory of Life Events and Strains (YA-FILE, McCubbin, Patterson and Grochowski $\left(1984^{4}\right)$ - modificiran prema A-FILE, mjeri stres i poteškoće oko prilagodbe prilikom tranzicije mladih ljudi na fakultet; 77 čestica.

- Parenting Daily Hassles Scale (Crnic i Grenberg, 1990, Crnic i Booth, 1991) - skalu popunjavaju roditelji i procjenjuje se frekvencija i intenzitet iskustva koja za roditelje mogu biti „teška"; koristi se u istraživanjima s roditeljima koji imaju velike poteškoće u odgoju djece; 20 čestica.

- The Recent Life Events Questionnaire (modificirano prema Brugha i suradnici, 1985, prema Cox i Bentovim, 2000) - namijenjen je procjeni socijalne povijesti te se procjenjuje koliki utjecaj imaju događaji iz obiteljske povijesti; 21 čestica.

\section{Zaštitni čimbenici / mehanizmi}

Zaštitnima se nazivaju čimbenici koji su se u raznim istraživanjima utvrdili kao oni koji u interakciji s rizikom doprinose otpornosti obiteljskog sustava, a identificirani su na razini člana obitelji, cjelokupne obitelji ili pak zajednice (Patterson, 2002a). Slično navode i Khanlou i Wray (2014) ističući kako na otpornost kako svakog člana obitelji, pa tako i obitelji kao sustava, utječu individualni čimbenici otpornosti i obilježja okuženja, poput jednakih šansi, socijalne pravde, zakona, socijalne politike i slično. Pri tome je važno imati na umu kako važnost pojedinih zaštitnih čimbenika ovisi o vrsti rizika. Primjerice, u istraživanju individualne otpornosti (Maurović, 2015), razlika između "otpornih" i "neotpornih" u suočavanju s velikim životnim događajima, bila je u 3 zaštitna čimbenika na razini pojedinca (svijest o sebi i samoučinkovitost, ciljevi i težnje, rješavanje problema) te 4 zaštitna čimbenika u okruženju (mogućnost sudjelovanja u hobijima i interesima u školi i zajednici, visoka očekivanja od strane prijatelja, sudjelovanje u odlučivanju i važnim stvarima u domu i školi). Drugi potencijalni zaštitni čimbenici (primjerice brižni odnosi s članom obitelji/ odgajateljem i slično) nisu se pokazali važnima za ove mlade, prilikom suočavanja s ovim rizicima.

U pregledu 43 istraživanja koja su se bavila obiteljskom otpornosti, Benzies i Mychasiuk $(2008,2009)$ su identificirali 24 individualna zaštitna čimbenika te zaštitne čimbenike u obitelji ili zajednici koji doprinose otpornosti obitelji. Kao individualne čimbenike navode: unutrašnji lokus kontrole, sposobnost prepoznavanja i kontrole emocija, postojanje sustava vjerovanja (religijskog

4 http://www.mccubbinresilience.org/measures.html 
Martina Ferić, Ivana Maurović, Antonija Žižak: Izazovi istraživanja otpornosti obitelji

ili nekog drugog), samoučinkovitost, učinkovite strategije nošenja sa stresom, višu razinu obrazovanja ili vještina, dobro mentalno i fizičko zdravlje, lak temperament i ženski spol. Kao obiteljske čimbenike navode: strukturu obitelji (manje naprema većim obiteljima, jednoroditeljske obitelji naprema obitelji s oba roditelja, mlađe majke naprema starijim majkama), stabilnost partnerskog odnosa i dobra komunikacija, obiteljska povezanost, podržavajuće interakcije dijete-roditelj, osiguravanje kognitivno stimulirajućeg okruženja u domu od strane roditelja, vanjska mreža podrške, prilike za među generacijsko učenje, stabilni i dostatni prihodi i stanovanje u prikladnom prostoru. Kao čimbenike u zajednici navode: uključenost u zajednicu, prihvaćanje od strane vršnjaka, druge važne osobe u zajednici, sigurno susjedstvo te pristup dobrim obrazovnim institucijama i dobroj zdravstvenoj zaštiti.

Slično navode i Bhana i Bachoo (2011) te kao čimbenike otpornosti (koji su istovjetni zaštitnim čimbenicima) ističu (1) sustav vjerovanja i vrijednosti koji promiče optimistične stavove ili pomaže obiteljima u vrijeme izazova; predstavlja zajednički set stavova, načina razmišljanja i vrijednosti koji podržavaju pozitivne ishode za obitelj; (2) samostalnost i samoodređenje koje se gradi unutrašnjim lokusom kontrole; obitelji koje imaju naviku preuzimanja odgovornosti za svoju situaciju te koje su samostalnije češće se demonstrirati pozitivne ishode u vrijeme kriza; (3) duhovnost ili vjerovanje u višu silu se pokazala kao značajan „alat" u nošenju s izazovima; (4) autoritativan roditeljski stil obilježen toplinom, odgovaranjem na potrebe djeteta i komunikacijom, izravno promiče obiteljsku koheziju, koja se pokazala kao važan čimbenik obiteljske otpornosti; (5) obiteljska kohezija i toplina opisana kroz privrženost i emocionalnu podršku među članovima obitelji.

Nadalje, Black i Lobo (2008) navode kako se, na temelju pregleda literature koja se bavila konceptualizacijom otpornosti obitelji kao i istraživanja iste, kao važni čimbenici izdvajaju: pozitivan pogled, duhovnost, sklad članova obitelji, fleksibilnost, komunikacija u obitelji, financijsko upravljanje, obiteljsko vrijeme, rutine i rituali te mreža podrške obitelji.

Openshaw (2011) u svojoj doktorskoj disertaciji navodi sljedeće čimbenike koji jačaju otpornost obitelji: sustav vjerovanja, davanje smisla nedaćama, pozitivna perspektiva, transcendentalnost i duhovnost, organizacijski obrasci u obitelji, fleksibilnost, povezanost, socijalni i ekonomski resursi, komunikacija i procesi rješavanja problema, jasnoća, emocionalna ekspresija, zajedničko rješavanje problema. Slično navodi i Walsh (1996) te kao čimbenike koji doprinose otpornosti obitelji navodi: davanje smisla nedaćama, snagu i zadržavanje pozitivne perspektive, duhovnost i sustav vrijednosti te u kasnijim radovima (Walsh, 2003) dodaje i organizacijske kvalitete kao što su: fleksibilnost, povezanost, komunikacija i sposobnost korištenja resursa. 
Martina Ferić, Ivana Maurović, Antonija Žižak: Izazovi istraživanja otpornosti obitelji

Sheridan, Sjuts i Coutts (2013) navode kako su ključne karakteristike otpornih obitelji povezanost, prilagodljivost, komunikacija, afektivna prisutnost, uključenost, pozitivno roditeljstvo i rješavanje problema (Tablica 2.). Zajedno, ove karakteristike podržavaju obitelj u vrijeme izazova i krize, pomažući obiteljima da se uspješno prilagode novonastaloj situaciji.

Tablica 2. Obilježja otpornih obitelji (Sheridan, Sjuts i Coutts, 2013)

\begin{tabular}{|c|c|}
\hline Obilježje & Opis \\
\hline povezanost & $\begin{array}{l}\text { bliska emocionalna povezanost članova obitelji te razina samostalnosti koju } \\
\text { svaki član obitelji osjeća u obiteljskom sustavu }\end{array}$ \\
\hline $\begin{array}{l}\text { prilagodljivost/ } \\
\text { fleksibilnost }\end{array}$ & $\begin{array}{l}\text { sposobnost obitelji da modificira pravila, uloge i vodstvo kako bi ponovo } \\
\text { uspostavila ravnotežu između članova obitelji i obiteljskog sustava te } \\
\text { obiteljskog sustava i zajednice }\end{array}$ \\
\hline komunikacija & razmjena informacija, ideja, osjećaja između članova obitelji \\
\hline $\begin{array}{l}\text { afektivna } \\
\text { prisutnost }\end{array}$ & $\begin{array}{l}\text { spremnost člana obitelji da pokaže interes za i poštovanje prema } \\
\text { aktivnostima drugih članova obitelji }\end{array}$ \\
\hline $\begin{array}{l}\text { roditeljska } \\
\text { uključenost }\end{array}$ & $\begin{array}{l}\text { roditeljska predanost (psihološka, emocionalna i ponašajna) u podržavanju } \\
\text { učenja i razvoja djeteta }\end{array}$ \\
\hline $\begin{array}{l}\text { pozitivno } \\
\text { roditeljstvo }\end{array}$ & $\begin{array}{l}\text { osiguravanje sigurnog i poticajnog okruženja, stvaranje pozitivnog } \\
\text { okruženja za učenje, korištenje asertivne discipline, realna očekivanja i briga } \\
\text { o sebi kao o roditelju }\end{array}$ \\
\hline $\begin{array}{l}\text { rješavanje } \\
\text { problema }\end{array}$ & $\begin{array}{l}\text { sustavni proces koji omogućuje pojedincu formuliranje rješenja za } \\
\text { identificiranje problema }\end{array}$ \\
\hline
\end{tabular}

Iz navedenog je vidljivo kako autori navode iste ili slične čimbenike koji podržavaju razvoj obiteljske otpornosti. Isto tako, vidljivo je kako pri tome upotrebljavaju različite termine poput "zaštitni čimbenici”, „čimbenici koji jačaju otpornost”, „čimbenici otpornosti” i „obilježja otpornih obitelji". Uz to, zaštitni čimbenici imaju svoje "podnazive" ovisno i o tome dovode li do dobrih razvojnih ishoda izravno ili preko interakcije s rizicima. Tako se čimbenici/mehanizmi koji ne djeluju izravno na rizike, već neovisno o njima utječu na dobre ishode u literaturi nazivaju kompenzatorni (Jimerson i sur., 2004), „promotivni mehanizmi“ (Luthar i Zelazo, 2003, Fergus i Zimmerman, 2005), odnosno "snage, prednosti, resursi" (Leffert i sur., 1998, Sameroff i Fiese, 2000, prema Jimerson i sur., 2004). S druge strane, „zaštitni čimbenici/mehanizmi” su oni čimbenici/mehanizmi čije djelovanje ovisi o rizicima (Fergus i Zimmerman, 2005). Ipak, u literaturi o otpornosti često se ne slijede navedene podjele već se svi čimbenici nazivaju zaštitnima, neovisno o tome kako djeluju na rizike. 
Martina Ferić, Ivana Maurović, Antonija Žižak: Izazovi istraživanja otpornosti obitelji

Zaštitni čimbenici imaju važnu ulogu u poticanju procesa otpornosti. Naime, ključni cilj istraživanja otpornosti je identificiranje zaštitnih čimbenika koji mogu modificirati negativne učinke rizika na ishod, te nakon toga, identificirati mehanizme i procese koji su u podlozi pronađenih veza (Luthar i Cichetti, 2000, Masten, 2001, Rutter, 2000, 2003, prema Luthar, 2006). Pri tome valja imati na umu kako ne postoji jedinstveni odnos između određenog čimbenika, stresa i ishoda, već on varira ovisno o tome koji se čimbenik dovede u relaciju s kojom vrstom rizika, odnosno ishoda (Masten, 1988, prema Pierorazio, 2009, Luthar, 1991, Murray, 2003, Kumpfer, 1999, Fergus i Zimmerman, 2005).

Uz interakciju zaštitnih čimbenika s rizicima, za proces otpornosti važna je i interakcija raznih zaštitnih čimbenika unutar i izvan obitelji.

I dok su u literaturi opisani brojni instrumenti koji se koriste za mjerenje unutarnjih i vanjskih zaštitnih čimbenika pojedinca (za pregled vidjeti Windle, Bennett i Noyes 2011), manje je instrumenata za mjerenje zaštitnih čimbenika na razini obitelji. Neki od instrumenata koji se koriste za istraživanje zaštitnih čimbenika/mehanizama na razini obiteljskog sustava su:

- Family Resilience Assessment Survey (FRAS, autorica Sixbey, 2005) - mjeri obiteljsku otpornost kroz 6 područja: obiteljska komunikacija i rješavanje problema, korištenje ekonomskih i socijalnih resursa, zadržavanje pozitivne perspektive, obiteljska povezanost, sposobnost pronalaženja smisla u nedaćama i duhovnost obitelji, 66 čestica.

- Family Adaptability and Cohesion Evaluation Scale III (FACES III, autori Olson, Portner i Lavee, 1985), prema Olson, 1986) - mjeri tri dimenzije obiteljskog funkcioniranja: kohezija (emocionalne veze, obiteljske granice, prijatelji, obiteljske koalicije, vrijeme, prostor u kome obitelj provodi vrijeme, donošenje odluka u kući, interesi i rekreacija), fleksibilnost (ili obiteljske uloge, moć, kontrola, liderstvo, stil pregovaranja), komunikacija (vještine slušanja, vještine razgovaranja, jasnoća komunikacije i poštovanje sugovornika), 20 čestica.

- Family Adaptability and Cohesion Evaluation Scale IV (FACES IV, autori Olson, Gorall, i Tiesel, 2004), prema Olson i Gorral, 2006) - nastala modifikacijom FACES II i FACES III; mjeri koheziju, fleksibilnost, komunikaciju sadrži posebnu skalu kojom se ispituje zadovoljstvo obiteljskim životom, 42 čestice. 


\section{Dobri ishodi}

Pri operatcionalizaciji dobrih ishoda izrazito je važno imati na umu kako je kulturalna osviještenost od iznimne važnosti pri konceptualizaciji otpornosti obitelji, odnosno poimanju što su dobri ishodi za nekog pojedinca ili obitelj u cjelini (Walsh, 2013). „Otporni” odgovor obitelji u situacijama rizika ovisi o vrijednostima kulture u kojoj obitelj živi. Drugim riječima, ovisi o odnosu prema specifičnoj rizičnoj situaciji i očekivanjima u odnosu na obiteljsko nošenje sa situacijom i adaptacijom na nju (Sheridan, Sjuts i Coutts, 2013).

Dobar ishod na razini obitelji može se operacionalizirati kao obiteljska prilagodba (FAAR model, Patterson, 1988). Pri tome se ona definira kao proces vraćanja ravnoteže između zahtjeva koji se postavljaju pred obitelji (različitih rizika) i sposobnosti obitelji da se nosi s tim zahtjevima. Tada se dobar ishod očituje u (1) kontinuiranoj sposobnosti obitelji da promovira razvoj članova obitelji; (2) spremnosti za održavanje obiteljske cjelovitosti kako bi obitelj mogla odgovoriti na zadatke različitih životnih ciklusa u kojima se nađe.

Dobar ishod obitelji može se operacionalizirati i kroz kompetentnost obitelji za ispunjavanje funkcija obitelji (Ooms, 1996, prema Patterson, 2002b). Neke od obiteljskih funkcija, prema Oomsu (1996, prema Patterson, 2002b) su: (1) kreiranje obitelji i definiranje uloga članova obitelji; (2) njegovanje i socijalizacija članova obitelji; (3) ekonomska podrška; (4) zaštita ranjivih članova. Ukoliko se dobri ishodi operacionaliziraju na ovaj način, potencijalno se javlja opasnost jasnog razdvajanja zaštitnih čimbenika i ishoda u istraživanjima. Primjerice, zaštita ranjivih članova može se poimati kao dobar ishod neke obitelji dok u isto vrijeme može biti zaštitni čimbenik koji doprinosi nekom drugom (dobrom) ishodu.

Uz važnost jasnog razlikovanja dobrih ishoda od zaštitnih čimbenika, Patterson (2002b) navodi kako je iznimno važno razlikovati i ishode na razini pojedinca od ishoda na razini obitelji. Ova preporuka još je važnija uzme li se u obzir definicija prema kojoj je sustav (obiteljski) više od zbroja međusobnih članova (Taylor, 2013). Dakle, kako bi se govorilo o dobrom funkcioniranju obitelji nije dovoljno „izmjeriti” dobro funkcioniranje svakog člana, već je važno da cjelokupni obiteljski sustav ima obilježje dobrog ishoda.

Važno je istaknuti da u literaturi o otpornosti obitelji nema dovoljno dostupnih instrumenata kojima se mjeri dobar ishod na razini obitelji. Neki od instrumenata koje je moguće koristiti u tu svrhu su: 
Martina Ferić, Ivana Maurović, Antonija Žižak: Izazovi istraživanja otpornosti obitelji

- The Family Assessment Device (FAD) (Epstein, Baldwin i Bishop, 1983, prema Mansfield, Keitner i Dealy, 2015) - mjeri razinu obiteljskog funkcioniranja na nekoliko područja: rješavanje problema, komunikacija, uloge, afektivni odgovor, afektivna uključenost, kontrola ponašanja i opće funkcioniranje; 53 čestice.

- Family Member Well-being Index (FMWB, autori McCubbin Patterson, 19825) - mjeri stupanj do kojeg su se obitelji prilagodile u terminima skrbi za zdravlje, napetosti, energije, radosti, straha, ljutnje, tuge i opće skrbi; 8 čestica.

- Family Quality of Life Survey (FQOL, autor Beach Center on Disability, prema Hoffman i sur., 2006) - mjeri 10 dimenzija: orijentacija na obitelji (obiteljske interakcije, svakodnevni život, financijska dobrobit, roditeljstvo); individualna orijentacija (fizičko okruženje, emocionalna dobrobit, socijalna dobrobit, zdravlje, produktivnost, zastupanje); 24 čestice.

- Family Satisfaction Scale (Olson, 2011) - je skala unutar instrumenta FACES IV, koja mjeri zadovoljstvo članova obitelji različitim aspektima obitelji (kohezivnosti i fleksibilnosti i komunikacijom). Riječ je o zadnjem dijelu instrumenta koji prethodno ispituje koliko je obiteljska kohezivnost i fleksibilnost uravnotežena te kakva je komunikacija među članovima obitelji. Prvi dio instrumenta može služiti za mjerenje zaštitnih čimbenika, dok Family Satisfaction Scale može služiti za mjerenje dobrih ishoda; ovaj dio instrumenta sadrži 10 čestica.

Uz navedene izazove operacionalizacije rizika, zaštitnih čimbenika/mehanizama te dobrih ishoda, u istraživanjima otpornosti obitelji važno je voditi računa o teškoći istraživanja samog procesa otpornosti. Iz tog razloga, veliki broj autora (Bryman, 2007, Creswell, 2003, Johnson, Onwuegbuzie, Turner, 2007, Mason, 2006, prema Este, Sitter, Maclaurin, 2009) preporučuje da se u istraživanjima otpornosti koristi kombinirani pristup kako bi se produbilo razumijevanje o različitim mogućim načinima na koji zaštitni čimbenici/mehanizmi doprinose dobrim ishodima. Također, pri operacionalizaciji otpornosti obitelji važno je obratiti pozornost na vremensku perspektivu (Ferguss i Zimmerman, 2005, Walsh, 2013). Današnje je gledište da je jedino longitudinalnim istraživanjima moguće utvrditi kako jedinstveni čimbenici unutar i izvan obitelji svojom interakcijom tijekom vremena potiču proces otpornosti. Razlog takvog stajališta leži upravo u činjenici da otpornost nije stabilna karakteristika kroz vrijeme, te da manifestacija otpornosti ovisi o mnogim čimbenicima poput osobnih karakteristika/vještina/vjerovanja i/ili karakteristika sustava, dostupnim resursima i razini rizika s kojom se sustav (obitelj) suočava.

5 http://www.mccubbinresilience.org/measures.html 
Iz svega navedenog, jasno je kako je definiranje nacrta istraživanja otpornosti izrazito kompleksno te da je na svakom koraku potrebno jasno argumentirati odabranu konceptualizaciju / operacionalizaciju.

\section{ZAKLJUČAK}

U području istraživanja otpornosti obitelji puno je neodgovorenih pitanja. No, otpornost obitelji je koncept koji otvara prostor za osnaživanja obitelji u suočavanju sa životnim nedaćama na pozitivan način i uz zdravo funkcioniranje obitelji. Stoga se čini važnim ulagati u istraživanja kako bi se došlo do mogućih novih konceptualnih i metodoloških rješenja, kao i planiranja znanstveno utemeljenih intervencije utemeljenih na konceptu otpornosti. Polazeći od izazova s kojima su se susretala dosadašnja istraživanja u svakom novom istraživanju važno je jasno operacionalizirati koncept otpornosti obitelji. To uključuje radne definicije komponenti otpornosti - rizika, zaštitnih čimbenika/mehanizama $\mathrm{i}$ ishode te načina njihovog mjerenja.

Neki od ključnih izazova pri definiranju rizika odnose na obuhvat relevantnih i značajnih rizika za populaciju koja je u fokusu. Također, značajan izazov u istraživanju otpornosti obitelji je i jasno razdvajanje varijabli koje opisuju zaštitne čimbenike od onih koji opisuju ishode. Nadalje, pri definiranju dobrih ishoda za obitelji, potrebno je imati na umu širi kontekst u kojem se istraživanje provodi te voditi računa o vrijednosnom sustavu istraživača, odnosno ciljane skupine. Važno je i konceptualizirati i opisati razliku između zaštitnih mehanizama i ishoda na individualnoj i razini obiteljskog sustava (Patterson, 2002b). I na kraju, obuhvat i mjerenje dinamičnog i promjenjivog procesa otpornosti izrazito su izazovni te se stoga, pri istraživanjima u ovom području, preporuča korištenje kombiniranog pristupa i longitudinalnih istraživanja (Schoon, 2006).

Imajući u vidu sve navedeno te zahtjeve koji proizlaze iz postavljenih ciljeva ovog istraživanja, a koji se odnose na utvrđivanje obilježja otpornosti obitelji čiji su članovi korisnici različitih intervencija u različitim sustavima (odgoj i obrazovanje, socijalna skrb, zdravstvo, pravosuđe), u istraživanju se polazi od sljedećih radnih definicija:

Otpornost se razumije kao kapacitet dinamičnog sustava da se odupre ili oporavi od značajnih izazova koji prijete njegovoj stabilnosti, održivosti ili razvoju (prema Masten, 2011).

Otpornost obitelji - proces učinkovitog prevladavanja i prilagođavanja značajnom izvoru stresa ili traume (rizika); snage i resursi unutar pojedinca, obitelji i okoline (zaštitni čimbenici) potiču 
Martina Ferić, Ivana Maurović, Antonija Žižak: Izazovi istraživanja otpornosti obitelji

taj kapacitet za prilagodbu i oporavak (dobar ishod) u situaciji nedaće; tijekom života, iskustvo otpornosti će varirati (prilagođeno prema Windle, 2011).

Rizik - biološki, psihološki, socijalni, ekonomski i drugi događaji/okolnosti/obilježja koji mogu u značajnoj mjeri povećavati vjerojatnost negativnih razvojnih ishoda (Roisman, 2005, prema Windle, 2011).

Veliki životni događaji/,veliki stresori“ - traumatični i akutni životni događaji koji se rijetko pojavljuju, ali se smatraju razornima (Holmes i Rahe, 1967, Johnson, 1986, sve prema Clements, Aber i Seidman, 2008).

Zaštitni čimbenici - Snage i resursi unutar i izvan obitelji koji potiču kapacitet za prilagodbu i oporavak u situaciji nedaće (prilagođeno prema Windle, 2011).

Zaštitni mehanizam/proces - način na koji zaštitni čimbenik poboljšava ishode u slučaju izloženosti riziku (Luthar, Sawyer i Brown, 2006).

Očekuje se da će istraživanje Specifična obilježja obitelji u riziku: doprinos razvoju kompleksnih intervencija dati neka nova saznanja koja mogu doprinijeti pojašnjavanju čimbenika i procesa, kako obiteljske, tako i individualne otpornosti. 


\section{LITERATURA}

Ajduković, M., Ručević, S. i Šincek, D. (2008): Istraživanje rasprostranjenost rizičnog i delinkventnog ponašanja djece i mladih u urbanim sredinama - dodatni poticaj za ciljanu prevenciju. Dijete i društvo. 10 (1/2). 27-47.

Berc, G. (2012): Obiteljska otpornost - teorijsko utemeljenje i primjena koncepta u socijalnom radu. Ljetopis socijalnog rada. 19 (1). 145-167.

Bhana, A., Bachoo, S. (2011): The determinants of family resilience among families in low- and middle-income contexts: a systematic literature review. South African Journal of Psychology. 41 (2). 131-139.

Black, K., Lobo, M. (2008): A Conceptual Review of Family Resilience Factors. Journal of Family Nursing. 14 (1). 33-55.

Blažević, S. (2012): Komponente obiteljske otpornosti. Specijalistički rad. Sveučilište u Zagrebu. Edukacijsko-rehabilitacijski fakultet

Benzies, K., Mychasiuk, R. (2008): Fostering family resilience: A review of the key protective factors. Child and family social work. 14. 103-114.

Benzies, K., Mychasiuk, R. (2009): Fostering family resiliency: A review of the key protective factors. Child \& Family Social Work, 14. 10-114.

Clements, M., Aber, J. L., Seidman, E. (2008): The dynamics of life stressors and depressive symptoms in early adolescence: a test of six theoretical models. Child Development. 79 (4). 1168-1182.

Cox, A., Bentovin, A. (2000): The Family Pack of Questionnaires and Scales. Department of Health, The Stationery Office Ltd. Retrieved 14. April, 2016. from http://www.teescpp.org. uk/Websites/safeguarding130315/images/Documents/Family-pack-of-scales-andquestionnaires.pdf

Crnic, K. A., Greenberg, M. T. (1990): Minor parenting stresses with young children. Child Development. 61. 1628-1637.

Crnic, K. A., Booth, C. L. (1991): Mothers' and fathers' perceptions of daily hassles of parenting across early childhood. Journal of Marriage and the Family. 53. 1043-1050.

DeFrain, J., Asay, S. M. (2007): Strong Families Around the World: An Introduction to the Family Strengths Perspective. Marriage \& Family Review, 41(1-2). 1-10. 
Martina Ferić, Ivana Maurović, Antonija Žižak: Izazovi istraživanja otpornosti obitelji

Este, D., Sitter, K. C., MacLaurin, B. (2009): Using mixed methods to understand resilience. U: Liebenberg, L., Ungar, M. (ur.), Researching Resilience Toronto: University of Toronto Press, 201-224.

Ferić Šlehan (2008): Rizični i zaštitni čimbenici u obiteljskom okruženju: razlike u procjeni mladih i njihovih roditelja. Hrvatska revija za rehabilitacijska istraživanja. 44 (1).15-26.

Ferić Šlehan, M., Kranželić, V. (2008): Procjena zaštitnih i rizičnih čimbenika u zajednici: razlike između percepcije mladih i njihovih roditelja. Kriminologija i socijalna integracija. 16(1). 33-43.

Fergus, S., Zimmerman, M. A. (2005): Adolescent resilience: A framework for understanding healthy development in the face of risk. Annual review of public health. 26. 399-419.

Gauvin - Lepage, J., Lefebvre, H., Malo, D. (2014): Family resilience: Defining concept from a humanistic perspective. Interdisciplinary Journal of Family Studies. XIX. 22-36.

Hawley, D. R. (2013): The Ramifications for Clinical Practice of a Focus on Family Resilience. U: Bevcar, D.S. (ur). Handbook of Family Resilience. Springer. 31-49.

Henry, C., Sheffield Morris, A., Harrist, A.W. (2015): Family Resilience: Moving into the Third Wave. Family Relations. 64 (1). 22-43.

Hoffman, L., Marquis, J., Poston, D., Summers, J. A., \& Turnbull, A. (2006): Assessing family outcomes: Psychometric evaluation of the beach center family quality of life scale. Journal of Marriage and Family. 68(4). 1069-1083.

Janković, J. (2008): Obitelj u fokusu. Zagreb: Etcetera-d.o.o.

Jimerson, S. R., Sharkley, J. D., Nyborg, V., Furlong, M. J. (2004): Strength-based assessment and school psychology: A summary and synthesis. The California School Psychologist. 9. 9-19.

Khanlou, N., Wray, R. (2014): A whole community approach toward child and youth resilience promotion: A review of resilience literature. International Journal of Mental Health and Addiction. 12. 64-79.

Koller Trbović, N., Žižak, A., Jeđud, I. (2009): Nezaposlenost i socijalna isključenost mladih u hrvatskoj: perspektiva nezaposlenih mladih u riziku ili s poremećajima u ponašanju. Kriminologija i socijalna integracija. 17 (2). 1-138. 
Martina Ferić, Ivana Maurović, Antonija Žižak: Izazovi istraživanja otpornosti obitelji

Kumpfer, K. L. (1999): Factors and processes contributing to resilience. The resilience framework. U: Glantz, M., Johnson, J. (ur.), Resilience and development: Positive life adaptations. Kluwer Academic/Pienum Publishers, New York. 179-224.

Lavee, Y., McCubbin, H. I., Olson, D. H. (1987). The Effect of Stressful Life Events and Transitions on Family Functioning and Well-being. Journal of Marriage and Family, 49. 857-873.

Lebedina - Manzoni (2000): Razvojne prednosti - pomoć pri razumijevanju i prevenciji rizičnih ponašanja adolescenata. Kriminologija i socijalna integracija: časopis za kriminologiju, penologiju i poremećaje u ponašanju. 8(1/2). 11-20.

Liebenberg, L., Ungar, M. (2009): Introduction: The challenges of researching resilience. U: Liebenberg, L., Ungar, M. (ur.), Researching Resilience. University of Toronto Press, $3-25$.

Luthar, S. S. (2006): Resilience in development: A synthesis of research across five decades. U: Cicchetti, D., Cohen, D.J. (ur.). Developmental Psychopathology: Risk, disorder and adaptation (second edition). Wiley, New York. 739-795.

Luthar, S. S., Ciccheti, D. (2000): The construct of resilience: Implications for interventions and social policies. Development and Psychopathology. 12 (4). 857-885.

Luthar, S., Cicchetti, D., Becker, B. (2000): The construct of resilience: A critical evaluation and guidelines for future work. Child Development. 7 (3). 543-562.

Luthar, S. S., Zelazo, L.B. (2003): Research on resilience. An integrative review. U: Luthar, S.S. (ur.). Resilience and Vulnerability: Adaptation in the Context of Childhood Adversities. Cambridge University Press. 510-551.

Mansfield, A.K., Keitner, G.I., Dealy,J. (2015): The Family Assessment Device: An Update. Family Process, 54(1). 82-93.

Masten, A.S. (2001): Ordinary Magic. Resilience Process in Development. American Psychologist. 56(3). 227-238.

Masten, A.S. (2007): Resilience in developing systems: Progress and promise as a fourth wave rises. Development and Psychopathology. 19. 921-930.

Masten, A. S. (2011): Resilience in children threatened by extreme adversity: Frameworks for research, practice, and translational synergy. Development and Psychopathology. 23. 493-506. 
Martina Ferić, Ivana Maurović, Antonija Žižak: Izazovi istraživanja otpornosti obitelji

Masten, A.S., Coatsworth, J.D. (1998): The development of competence in favorable and unfavorable environments. American Psychologist. 53. 205-220.

Masten, A.S., Monn, A.R. (2015): Child and family resilience: A call for integrated science, practice and professional training. Family Relations. 64. 5-21.

Masten, A. S., Powell, J. L. (2003): A resilience framework for research, policy, and practice. U: S. S. Luthar (ur.). Resilience and vulnerability: Adaptation in the context of childhood adversities. Cambridge University Press, New York. 1-25.

Mataga Tintor, A. (2011): Ostvarivanje prava djeteta u funkciji izgradnje otporne lokalne zajednice. Doktorski rad. Sveučilište u Zagrebu. Edukacijsko-rehabilitacijski fakultet.

Maurović, I. (2015): Otpornost adolescenata u dječjim domovima. Doktorska disertacija. Sveučilište u Zagrebu. Pravni fakultet

McCubbin, H. I. and Patterson, J. M. (1983a): The family stress process: the Double ABCX model of adjustment and adaptation. U: McCubbin, H. I., Sussman, M. B., Patterson, J. M. (ur.), Social Stress and the Family: Advances and Developments in Family Stress Theory and Research. The Haworth Press, New York. 7-37.

McCubbin, H. I., Patterson, J. M. (1983b): Family stress and adaptation to crises: a Double ABCX model of family behavior. U: Olson D. H., Miller, B. C. (ur.), Family Studies Review Yearbook (Vol. 1). Sage Publications. Beverly Hills, CA. 87-106.

Mihić, J., Musić, T., Bašić, J. (2013): Family risk and protective factors among young substance non - consumers and consumers. Kriminologija i socijalna integracija. 21(1). 1-165.

Murray, C. (2003): Risk factors, protective factors, vulnerability and resilience. Remedial \& Special Education. 24(1). 16-27.

Nichols, W. C. (2013): Roads to understand family resilience: 1920 to the twenty - first century. U: Bevcar, D.S. (ur.). Handbook of Family Resilience. Springer. 3-16.

O'Dougherty Wright, M., Masten, A. S., Narayan, A. J. (2013): Resilience processes in Development: Four waves on research of positive adaptation in the context of adversity. U: Goldstein, S., Brooks, R. B. (ur.). Handbook of Resilience in Children. 15-37.

Olson, D. H. (1986): Circumplex Model VII: Validation Studies and FACES III. Family Process. 25. 337-351.

Olson, D. H., Gorall, D. M. (2006): FACES IV \& the Circumplex Model. Preuzeto s: http://www.facesiv. com/pdf/3.innovations.pdf. Posjećeno: 14.4.2016. 
Martina Ferić, Ivana Maurović, Antonija Žižak: Izazovi istraživanja otpornosti obitelji

Olson, D. (2011): FACES IV and The Circumplex Model: validation Study. Journal of marital and Family Therapy. 3(1). 64-80.

Openshaw, K.P. (2011): The Relationship between family functioning, family resilience and quality of life among vocational rehabilitation clients. Doctoral thesis. Utah State University. Preuzeto s: http://digitalcommons.usu.edu/cgi/viewcontent. cgi? article $=2084 \&$ context $=$ etd. Posjećeno: 10.12 .2015 .

Patterson, J. (1988): Families experiencing stress: The family adjustment and adaptation response model. Family Systems Medicine. 5(2). 202-237.

Patterson, J. M. (2002a): Integrating family resilience and family stress theory. Journal of Marriage and Family. 64. 349-360.

Patterson, J. M. (2000b): Understanding family resilience. Journal of Clinical Psychology. 58(3). 233-246.

Pierorazio, D. A. (2009): A reframing of protective factors in the context of risk, adversity, and competence in adolescence. Doctoral thesis. Saint Marry University. Retrieved 5 March, 2013. from http://www.csm.edu/sites/default/files/Pierorazio.pdf.

Ricijaš, N. (2009): Pripisivanje uzročnosti vlastitog delinkventnog ponašanja mladih. Doktorska disertacija. Sveučilište u Zagrebu, Pravni fakultet.

Rutter, M. (1987): Psychosocial resilience and protective mechanisms. American Journal of Orthopsychiatry. 57(3). 316-331.

Rutter, M. (1999): Resilience concepts and findings: implications for family therapy.

Sheridan, S. M., Sjuts, T. M., Coutts, M. J. (2013): Understanding and Promoting the Development of Resilience in Families U: Goldstein, S., Brooks, R. B. (ur.) Handbook of Resilience in Children (second edition). Springer, 143-160.

Schoon, I. (2006). Risk and resilience: Adaptations in changing times. Cambridge: Cambridge University Press.

Simon, J. B., Murphy, J. J., Smith, S. M. (2005): Understanding and fostering family resilience. The Family Journal: Counseling and Therapy for Couples and Families. 13. 42-436.

Sixbey, M.T. (2005): Development of the Family resilience assessment scale to identify family resilience constructs. Doctoral Dissertation. University of Florida. Retrieved 10 Januray, 2016. from http://ufdc.ufl.edu/UFE0012882/00001. 
Martina Ferić, Ivana Maurović, Antonija Žižak: Izazovi istraživanja otpornosti obitelji

Sladović Franz, B. (2003): Psihosocijalni razvoj djece u dječjim domovima. Državni zavod za statistiku. Pravni fakultet Sveučilišta u Zagrebu.

Taylor, S.D. (2013): Family resilience model of behavioral health for low - income ethnic minority families. Doctoral thesis. Loma Linda University. Preuzeto s: http://scholarsrepository. llu.edu/cgi/viewcontent.cgi?article $=1154 \&$ context $=$ etd. Posjećeno: 10.01.2016.

Ungar, M. (2011): The social ecology of resilience. Addressing contextual and cultural ambiguity of a nascent construct. American Journal of Orthopsychiatry. 81. 1-17.

Ungar, M. (2013): Family Resilience and At-Risk Youth. U: Bevcar, D.S. (ur). Handbook of Family Resilience.Springer. 137-153.

VanBreda, A. D. P. (2001): Resilience theory: Literature review. Preuzeto s: http://www.vanbreda. org/adrian/resilience/resilience_theory_review.pdf. Posjećeno: 2.11.2015.

Vulić-Prtorić, A. (2002): Obiteljske interakcije i psihopatološki simptomi u djece i adolescenata. Suvremena psihologija. 5(1). 31-51.

Žižak, A., Ratkajec, G., Nikolić, B., Maurović, I., Mirosavljević, A. (2010): Jake strane djece i mladih, korisnika institucionalnog tretmana. Odgojne znanosti. 12(1). 7-28.

Walsh, F. (1996): The Concept of Family Resilience: Crisis and Challenge, Family Process, 35(3). 261-281.

Walsh, F. (2003): Family resilience: a framework for clinical practice. Family Process. 42(1). 1-18.

Walsh, F. (2013): Community - based practice applications of a family resilience framework. U: Becvar, D.S. (ur.), Handbook of Family Resilience. Springer. 65-82.

Wilmoth, J. D., Smyser, S. (2009): The ABC-X model of family stress in the book of Philippinas. Journal of Psychology and Theology. 37(3). 155-162.

Windle, G. (2011): What is resilience? A review and concept analysis. Reviews in Clinical Gerontology. 21. 152-169.

Windle, G., Bennett, K. M., Noyes, J. (2011): A methodological review of resilience measurments scales. Health and Quality of Life Outcomes. 9(8). 1-18. 


\section{Challenges in family resilience research ${ }^{6}$}

\section{Summary}

Resilience is a concept that has been increasingly explored in the field of psychosocial science. This also sheds light on number of ambiguities in the conceptualization and operationalization of this phenomenon. Through fifty years of development, the concept went from the individual to the broader environment of individual (family, community, culture). Accordingly, ambiguities that appeared in the field of individual resilience were transferred to the field of family and community resilience. The aim of this paper is to provide an overview of family resilience conceptualization, in the contemporary literature. Furthermore, operationalization of family resilience concept in the research Specific characteristics of families at risk: contribution to complex interventions planning (Faculty of Education and Rehabilitation Sciences, University of Zagreb) is presented in the paper.

Key words: resilience, family resilience, conceptualisation challenges

6 This paper has been fully supported by Croatian Science Foundation under the project IP-2014-09-9515. 